\title{
Non-random Chromosomal Aberrations in Peripheral Blood Leucocytes of Gastrointestinal Tract and Breast Cancer Patients
}

\author{
Kamlesh Guleria ${ }^{1}$, Hardeep Pal Singh ${ }^{2}, J^{J a g m o h a n ~ S i n g h}{ }^{2}$, Harpreet Kaur $^{2}$ and Vasudha Sambyal ${ }^{2}$ \\ 1. Centre for Genetic Disorders/ Department of Human Genetics, 2. Human Genetics \\ Department, Guru Nanak Dev University, Amritsar 143 005, Punjab, India
}

KEYWORDS Non-random; chromosomal aberrations; leucocytes; cancer

\begin{abstract}
Chromosomal instability was studied in cultured peripheral blood leucocytes to assess whether peripheral blood had non-random cytogenetic aberrations as observed in tumor tissue. The study was conducted on sporadic breast and gastrointestinal tract cancer patients from an area having increased incidence of these cancers. The study sample was of 38 sporadic (26 gastrointestinal tract and 12 breast) cancer patients and 30 controls subjects. Cancer patients had significantly increased (20-68\%) aberrant metaphases compared to controls $(6.2 \%)$. In patients, the aberrations seen were loss or gain of chromosomes, polyploidy, chromatid breaks and gaps, acentric fragments, marker chromosomes, double minutes and acrocentric associations. In oesophageal cancer loss of chromosome 2, $7 \mathrm{q}-, 10,11,12,15,17,19,21$, and $\mathrm{Y}$ and gain of chromosome 3, 4, 10, 19, and 22; in gastric cancer loss of 11q and $\mathrm{X}$, gain of extra $\mathrm{C}$ group like marker chromosome and in breast cancer loss of $1,2,5,7,11,12,13,15,16,18,22$, and $X$ and gain of chromosome 2q, 13, 19 and 20 were seen. Chromatid breaks were seen on chromosomes $1 p, 2 p, 2 q$ and $4 \mathrm{q}$ while chromatid gaps were on chromosomes 1p, 2p, 3p, and 3q only. Aberrations involving specific chromosomes i.e. $2,7,11,12,15,19,22$ and $\mathrm{X}$ in lymphocytes of cancer patients having cancers of diverse sites indicate that the patients probably have a constitutional chromosomal instability which participates in cancer predisposition and there is involvement of some common genes in tumor initiation and development.
\end{abstract}

\section{INTRODUCTION}

Cancer is a disease caused by mutation in genes that give a selective advantage to the growth of tumor cell. A tumor has many genetic alterations acquired in course of a long clonal evolution. The pattern of abnormalities varies from simple rearrangement to complex abnormalities affecting both chromosome structure and number (Mitelman Data Base of Chromosome Aberrations in Cancer 2001). Genetic instability is considered as a poor prognostic factor in many types of cancers implying that cellular processes that lead to the gain, loss or rearrangement of genomic DNA are important in evolution of metastatic tumor cells (Usmani, 1993). Chromosomal instability can contribute to tumor progression by several possible mechanisms: (1) Loss of chromosomes that harbor genes encoding negative regulators of cell cycle progression, proteins involved in apoptosis or senescence or suppression of uncontrolled cell growth, metastasis and invasion. (2) Gain of extra chromosomes that harbor oncogenes encoding positive regulators of cell cycle progression, antiapoptotic proteins and proteins that suppress senescence.

Corresponding Author: Vasudha Sambyal

E-mail:vasudhasambyal@yahoo.com
Specific types of chromosomal aberrations have been identified in different tumors. These reflect genomic changes contributing to transformation of normal cells to tumor cells, promoting cell proliferation and viability. Epithelial tumors show gain and loss of distinct chromosomal regions reflecting copy number changes of oncogenes and tumor suppressor genes whereas hematological tumors have more translocations. The principal biological mechanisms causing either reciprocal translocations, chromosome gain or loss have not been identified yet.

Similar genes have been implicated in tumorigenic process in tumors of diverse sites. Germline mutations in E-cadherin have been reported in families with early-onset diffuse gastric cancer and loss of function of this gene has been implicated in pathogenesis of earlyonset colorectal and breast cancers. E-cadherin is expressed on the cell surface in epithelial tissues and its gene product plays a role in epithelial tumorigenesis (Knudsen et al. 1998). The mutation in BRCA2 gene increases the risk of getting pancreatic, stomach and gallbladder cancer apart from breast cancer (www.cancerpage. com/cancernews/cancernews41.htm). 
Chromosomal instability has been reported in tumor tissue as well in other tissues like peripheral blood leucocytes in retinoblastoma (Czeizel et al. 1974; Takabayashi et al. 1983; Nunez et al. 1984), breast cancer (Madhavi et al. 1990; Uday Kumar and Bhargawa 1994; Cervantes and Glassman 1996; Roy et al. 2000), colorectal cancer (Dave et al. 1993; Richard et al. 1994), renal cell carcinoma (Wang et al. 1982), skin cancers (Nordenson et al. 1984) and in skin fibroblasts in Multiple Endocrine Neoplasia-1 (Scappaticci et al. 1991).

The frequency of sporadic gastrointestinal and breast cancer is higher in areas adjoining Amritsar city of Punjab state, India. Amritsar city has small-scale industry including textile processing, woollen dyeing, steel foundries etc. and area adjoining the city is agriculture land. The main crops grown in this area are wheat and rice and use of pesticides and chemical fertilizers is high. In the present work chromosomal instability was studied in peripheral blood leucocytes of gastrointestinal tract and breast cancer patients to assess whether peripheral blood had any specific cytogenetic aberrations as observed in tumor tissue.

\section{MATERIALANDMETHODS}

A peripheral blood sample of 38 cancer patients (26 gastrointestinal tract and 12 breast cancer) was collected under informed consent prior to operation from the surgical wards of various hospitals at Amritsar city according to the guidelines of ethical committee constituted by Guru Nanak Dev University Amritsar (Punjab, India). Relevant informations including symptoms, duration of the disease, habits, habitat, occupation, pathological status and exposure to mutagens were recorded on predesigned questionnaire. Blood samples of 30 age and sex matched controls (10 males and 20 females) was collected from Amritsar city and surrounding areas (Table 1). Cultures were set up in RPMI 1640 medium (Hi-Media Lab., India) at $37^{\circ} \mathrm{C}$ for 72 hours according to standard culturing technique (Moorhead et al. 1960) with some modifications. The lymphocytes were treated with $0.075 \mathrm{M} \mathrm{KCl}$ at room temperature for 22 minutes and fixed with carnoy's fixative (1 part glacial acetic acid and 3 parts methanol). Airdried and aged slides were GTG banded (Benn and Perle 1986 method). Metaphases were analysed for gross chromosomal aberrations.

\section{RESULTS}

The duration of the disease varied from one month to one year. 25 patients ( 12 males and 13 females) were rural and belonged to low socioeconomic group. 9 male patients had agriculture as their main occupation and had an exposure to pesticides and chemical fertilizers; one male patient worked in textile mill and one in

Table 1: Detailed profile of cancer patients and controls

\begin{tabular}{|c|c|c|c|c|c|c|c|c|c|}
\hline & Controls & $\begin{array}{l}\text { Breast } \\
\text { cancer }\end{array}$ & $\begin{array}{l}\text { Oesophageal } \\
\text { cancer }\end{array}$ & $\begin{array}{l}\text { Gastric } \\
\text { cancer }\end{array}$ & $\begin{array}{l}\text { Colon } \\
\text { cancer }\end{array}$ & $\begin{array}{c}\text { Colorectal } \\
\text { cancer }\end{array}$ & $\begin{array}{l}\text { Rectal } \\
\text { cancer }\end{array}$ & $\begin{array}{l}\text { Pancreatic } \\
\text { cancer }\end{array}$ & $\begin{array}{l}\text { Gall bladder } \\
\text { cancer }\end{array}$ \\
\hline $\begin{array}{l}\text { No. of subject/ No. of } \\
\text { metaphases karyotyped }\end{array}$ & $30 / 450$ & $12 / 298$ & $11 / 244$ & $19-1$ & $10-1$ & $4-75$ & $4-35$ & $10-1$ & $4-76$ \\
\hline $\begin{array}{l}\text { Aberrant metaphases/ } \\
100 \text { metaphases scanned }\end{array}$ & 6.2 & 28.5 & 33.1 & 68.4 & 20 & 40 & 25.7 & 20 & 48.6 \\
\hline \multicolumn{10}{|l|}{ Type of abnormalities } \\
\hline Chromatid breaks (\%) & - & 2.3 & - & - & - & 20 & - & - & - \\
\hline Chromatid gaps (\%) & - & 1.1 & 8.6 & 46 & - & 10 & - & - & 16.2 \\
\hline Terminal deletion $(\%)$ & - & 1.1 & 1.2 & - & - & - & - & - & 8.1 \\
\hline Acentric fragments $(\%)$ & - & 4.7 & 7.4 & - & - & 13.3 & - & - & 18.9 \\
\hline Double minutes $(\%)$ & - & - & 3.7 & - & - & - & 11.1 & - & - \\
\hline Trisomy $(\%)$ & - & 3.5 & - & - & - & - & - & - & - \\
\hline Hypoploidy (\%) & - & 28.2 & 2.4 & - & - & - & 11.1 & - & - \\
\hline Hypodiploidy (\%) & - & - & 8.6 & - & - & 23.3 & - & - & 32.4 \\
\hline Marker $(\%)$ & - & 2.3 & - & 7.6 & - & - & - & - & 2.7 \\
\hline Ring $(\%)$ & - & 1.1 & - & - & - & - & - & - & - \\
\hline Translocation (\%) & - & 1.1 & 1.2 & - & - & - & - & - & - \\
\hline Loss of Y $(\%)$ & - & - & 4.9 & - & - & - & - & - & - \\
\hline Polyploidy (\%) & 1.3 & - & 17.2 & - & - & - & 33.3 & - & - \\
\hline $\begin{array}{l}\text { Acrocentric } \\
\text { associations }(\%)\end{array}$ & 4.8 & 54.1 & 44.4 & 46 & 20 & 33.3 & 44.4 & 20 & 21.6 \\
\hline
\end{tabular}


railway (Table 1). Out of 12 males 10 consumed alcohol (100-150 $\mathrm{ml}$ at a time) twice or thrice in a week. All the female patients were housewives. Among the controls 18 were rural, no control subject consumed alcohol or smoked.

The frequency and types of gross chromosomal aberrations observed in cancer patients and in controls are shown in Table 2. The frequency of aberrant metaphases varied from $20-68 \%$ in cultured leucocytes of cancer patients and was $6.2 \%$ in controls. A variety of chromosomal aberrations including gaps, breaks, terminal deletions, acentric fragments, double minutes, acrocentric associations, polyploidy, loss and gain of chromosomes, ring chromosome and marker chromosomes were seen in peripheral blood leucocytes of cancer patients. High frequency of acrocentric associations (D\&D, $D \& G, G \& G$ and $3 d$ chromosomes) were seen in all cancer patients. Loss of chromosome 2, 7q-, $10,11,12,15,17,19,21$, and $\mathrm{Y}$ and gain of chromosome $3,4,10,19$, and 22 in oesophageal cancer, loss of 11q and X, gain of extra C group like marker chromosome in gastric cancer, loss of

Table 2: Frequency of chromosomal aberrations in peripheral blood leucocytes of cancer patients and controls

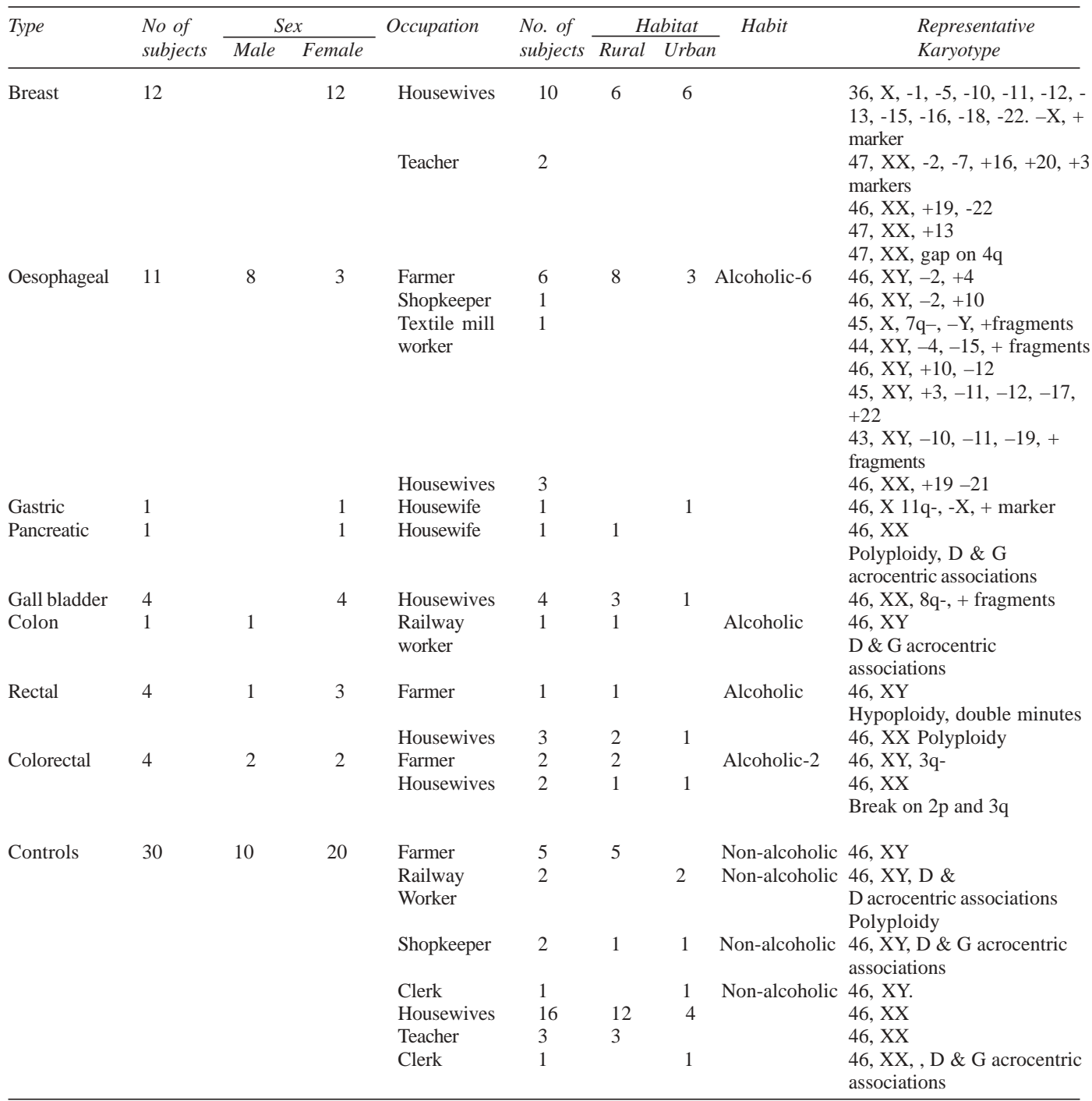


$1,2,5,7,11,12,13,15,16,18,22$, and $X$ and gain of chromosome 2 q, 13, 19 and 20 in breast cancer were seen. The controls had polyploidy and few acrocentric associations (D\&D and G\&G) only.

\section{DISCUSSION}

The chromosomal aberrations seen in peripheral blood leucocytes of cancer patients involved specific chromosomes and were similar to those previously reported in tumor tissues. In oesophageal and breast cancer, loss of chromosome 2, 7, 11, 12 and 15 and gain of chromosome 19 was observed. Chromosome 11 was also lost in gastric cancer whereas chromosome $\mathrm{X}$ was lost in gastric and breast cancer. Monosomy of chromosome 5,7, 11, 12, 16, 18, 19, and chromosome 22 (Rommel Rodriguez et al. 1992) loss of chromosome 2, 4, 6 and X (Malkhosyan 1998) have been reported in breast carcinoma.

Structural aberrations of chromosome 1, 2, 7, 12,17 and 21 in peripheral blood lymphocytes of colorectal cancer (Dave et al. 1993) and chromosome 1, 7, 11, 17, 1922 and $\mathrm{X}$ in tumor tissue of gastric carcinoma (Yadav et al. 1996) have been reported. Numerical changes affecting chromosome 4, 6, 7, 8, 9, 10, 11, 12, 17, 18, $\mathrm{X}$ and Y (Persons et al. 1998) and chromosome 7, 8,11, 17 and Y (Beuzen et al. 2000) have been reported in tumor tissue of oesophageal adenocarcinoma. The authors suggested that the aberrations of chromosome 7, 8,11, 17 and $\mathrm{Y}$ are associated with the early events during neoplastic transformation. Gain of chromosome 10 and loss of chromosome 15, $19 \&$ Y have also been seen in human oesophageal cancer cell line SLMT-1 (Tang et al. 2001). The abnormalities of the PTEN gene (10q23.3) are associated with the tumor progression, metastasis and survival (Kang et al. 2002). Loss of Y chromosome has been also reported in tumor tissue of oesophageal cancer patients (Wang et al. 1998; Dekken et al. 1999; Mayama et al. 2000; Beuzen et al. 2000 and Tang et al. 2001). The loss of Y chromosome which has a very limited genic content would make possible accumulation of $45, X$, cells, making the chromosome loss a subtle indicator of any alterations of chromosome segregation.

Chromatid breaks in breast and colorectal and chromatid gaps were seen in all categories of cancer studied except pancreatic cancer. Chromatid breaks were seen only on chromo- somes $1 p, 2 p, 2 q$ and $4 q$ while chromatid gaps were on chromosomes 1p, 2p, 3p and 3q (Table 1). Terminal deletion on chromosomes $2 \mathrm{q}, 3 \mathrm{q}$ and $8 \mathrm{q}$ were seen in GIT cancers. High frequency of breaks and gaps as compared to controls has previously been reported in breast carcinoma (Brown et al. 1985; Ardisia et al. 1993; Ray et al. 2001). Structural and numerical aberration of chromosome 2 (Gardner et al. 1982; Dave et al. 1993) and chromosome break involving 3p14 (Richard et al. 1994) in the lymphocytes of colorectal cancer and numerical and structural chromosomal aberrations involving chromosome 1 in tumor tissue of gastric Carcinoma (Han et al. 1996; Yadav et al. 1996) have been reported. Structural changes involving chromosome 8 (Shiraishi et al. 2001) in gall bladder carcinoma, hepatocellular and pancreatic carcinoma have been reported. Gaps and breaks have also been reported in tumor tissue (Hussain et al. 1996) and in peripheral blood leucocytes of breast cancer patients (Ochi et al. 1988). Loss of genetic information from $1 \mathrm{p}$ is considered as an early primary premalignant event in intestinal tumorigenesis (Bardi et al. 1993). The chromosomes/segments lost or gained may be harboring a gene involved in tumorigenesis It has been suggested that chromosomal instability leads to breaks occurring at different locations which increase the chances of damage and could activate an oncogene to initiate to build up a clone with the chromosome rearrangement that triggers the neoplastic transformation (Brown et al. 1985). The chromosomes containing gaps and breaks reported in the present study harbor many genes implicated in tumorigenesis such as TTC4 (1p31), PTGS2 (1q25.2-q25.3), ODC1 (2p25), MSH2 (2p21), PMS1 (2q31-33), MLH1 (3p21), $\beta$ Catenin (3p21.3), TGFBE2 (3p22), DLEC1 (3p22p21.3), FHIT (3p14.2), RASSF1A (3p21.3).

High frequency of polyploid cells (hypertriploid to tetraploid) as compared to controls was seen in oesophageal and rectal carcinoma. Polyploidy has been reported in tumor tissue of oesophageal cancer patients (Rabinovitch et al. 1989; Blount et al. 1990; Gupta 2001) and in peripheral blood leucocytes of breast cancer patients (Uday Kumar and Bhargawa 1994). Polyploidy is an indicator of fast growing tumors. Ploidy status is associated with the advancing stage of tumor but it is not statistically associated with the differentiation of tumor (Blant et al. 2001). The formation of 
aneuploid genome might be the initiating step in neoplastic conversion (Matzke et al. 2003).

Acentric fragments were seen in oesophageal, colorectal, gallbladder and breast carcinoma. Acentric fragments have also been reported in tumor tissue of oesophageal cancer patients (Gupta 2001) and in Multiple Endocrine Neoplasia-I (Scappaticci et al. 1991). The losses of chromosome and chromosome segments have been postulated to be the regions of candidate loci for tumor suppressor genes and dominantly acting growth regulatory gene.

Acrocentric associations (satellite associations) were seen in gastrointestinal as well as in breast cancer patients. Higher frequency of D\&G, D\&D and G\&G satellite associations were seen in cancer patients as compared to controls. Acrocentric associations are considered an indicator of acrocentic chromosomes to be involved in Robertsonion translocation. Double minutes were seen in oesophageal, colorectal and breast carcinoma. The cytogenetic phenomenon of double minutes has been associated with amplification of cellular oncogenes in several malignancies (Scappaticci et al. 1991). These have also been reported in tumor tissue of oesophageal squamous cell carcinoma (Rosenblum Vos et al. 1993), breast carcinoma (Baker and Hsu 1976; Gebhart et al. 1986; Madhavi et al. 1990; Uday Kumar and Bhargawa 1995).

High frequency of aberrations in peripheral blood leucocytes similar to those seen in tumor tissue indicated that defective genetic or molecular mechanisms expressed in tumor tissue are also manifested in similar manner in circulating lymphocytes of patients. Aberrations of chromosome 2, 7, 11, 12, 15, 19, 22 and $\mathrm{X}$ both in gastrointestinal and breast cancer indicate the involvement of some common genes in tumor initiation and development. Some common genes reported to be involved in gastrointestinal tumors and breast tumorigenesis are: MAP2K4 (on 17p11.2), EP300 (on 22q13.2), LKB1 (on 19p13.3), FGFR1 (on 8p11.2-p11.1), FHIT (on 3p14.2), PTEN (on 10q23.3), DLC-1 (on 8p22), APC (on 5p21q22), COX-2/PTGS2 (on 1q25.2-q25.3), bcl2 (on 18q21), CHEK2 (on 22q), E-cadherin (on 16q22.1), P53 (on 17p13.1), myc (on 8q24), K-ras (on 12p12), ErbB2 (on 17q11.2-q12), cyclinD1 (on 11q13), MSH2 (on 2p22-p21) and MLH1 (on 3p21.3). Aberrations involving specific chromosomes in cancers of diverse sites indicate that the cancer patients probably have a constitutional chromosomal instability which participates in cancer predisposition.

In present study, most of the patients had low socioeconomic status and $83.3 \%$ of the males consumed alcohol. Alcohol consumption increases all indices of lipid peroxidation and may promote carcinogenesis through excessive cell proliferation induced by altered lipid and eicosonoid metabolism. Apart from genetic factors, poor nutrition, lifestyle, exposure to carcinogenic pollutants and alcohol abuse are suspected to be a cause of these cancer. Understanding mechanisms underlying chromosomal instability in tumors and leucocytes in cancer patients can help in identifying potential targets to intervene in progression to malignancy.

\section{REFERENCES}

Ardisia C, Venti G, Colozza MA, Breschi C, Porfirio B, Davis S, Tonato M, Donti E 1993. Expression of aphidicolin-induced fragile sites in lymphocytes of patients with breast cancer. Cancer Genet Cytogenet, 67:147

Baker PE, Hsu TC 1979. Double minutes in human carcinoma cell lines with special reference to breast tumors. J Natl Cancer Inst, 162: 257-262.

Bardi G, Pandis N. Fenger C, Kronborg O, Bomme L, Heim S 1993. Deletion of 1 p36 as a primary chromosomal aberration in intestinal tumorigenesis. Cancer Res, 53: 1895-1898.

Benn PA, Perle MA 1986. Chromosome staining and banding techniques, Human Cytogenetics, A Practical Approach. Rooney DE and Czepulkowski BH (Ed) IRL Press Ltd, Oxford, England, 54 pp.

Beuzen F, Dubois S, Flejou JF 2000. Chromosomal numerical aberrations are frequent in oesophageal and gastric adenocarcinomas: A study using in-situ hybridization. Histopathol, 37: 241-249.

Blant SA, Ballini JP, Caron CT, Fontolliet C, Monnier P, Laurini NR 2001. Evolution of DNA ploidy during squamous cell carcinogenesis in the esophagus. Dis Esophagus, 14: 178-184.

Blount PL, Rabinovitch PS, Reid BJ 1990. Early Barrett's Adenocarcinoma arises within a single aneuploid population. Gastroenterol, 98: 273.

Breast cancer gene may increase risk for pancreatic cancer. (c.f.) www.cancerpage.com/cancernews/ cancernews41.htm

Brown T, Dawson AA, McDonals JA, Bullock I, Watt JL 1985. Chromosome damage and sister chromatid exchanges in lymphocyte cultures from patients with two primary cancers. Cancer Genet Cytogenet, 17: $35-42$.

Cervantes M, Glassman AB 1996. Breast cancer cytogenetics: a review proposal for clinical application. Ann Clin Lab Sci, 26: 208-214.

Czeizel A, Crosz L, Gardonyi J, Remenar K, Ruziscka P 1974. Chromosome studies in twelve patients with retinoblastoma. Humangenetik, 22: 159-166. (c.f.) 
Barrios L, Caballin MR, Miro R, Fuster C, Guedea F, Subias A, Egozene J 1991. Chromosomal instability in breast cancer patients. Hum Genet, 88: 39-41.

Dave BJ, Hopwood VL, Hughes JI, Jackson GL, Melillo D, Pathak S 1993. Cytogenetic abnormalities in colon cancer patients: a comparison of $\mathrm{T}$ and $\mathrm{B}$ lymphocytes. Anticancer Res, 13: 433-438.

Dekken HV, Geelen E, Dinjene WNM, Wijnhoven BPL, Tilanus HW, Tanke HJ, Rosenberg C 1999. Comparative genomic hybridization of cancer of gastroesophageal junction: Deletion of 14q31-32.1 discriminates between esophageal and gastric cardia adenocarcinomas. Cancer Res, 59: 748-752.

Gardner EJ, Rogers SW, Woodward S 1982. Numerical and structural chromosome aberrations in cultured lymphocytes and cutaneous fibroblasts of patients with multiple adenoma of colorectum. Cancer, 49:1413-1419.

Gebhart E, Bruderlein S, Augustus M, Siebert E, Feldner J, Scmidt W 1996. Cytogenetic studies on human breast carcinomas. Breast Cancer Res Treat, 54: 59-64.

Gupta S 2001. Cytogenetic studies in human carcinoma of esophagus. (c.f.) http://mail.medacad.org/ www.ichg2001.org /abstracts/cancercyto.htm

Han K, Oh EJ, Kim YS, Kim YG, Lee KY, Kang CS, Kim BK, Kim WI, Shim IS, Kim SM 1996. Chromosomal numerical aberrations in gastric carcinoma: analysis of eighteen.cases using in situ hybridization. Cancer Genet Cytogenet, 92: 122-129.

Hussain SA, Balasubramanian S and Bamezai R 1996. Chromosomal breaks and gaps in breast cancer patients. Cytologia, 61: 47-51.

Kang YH, Lee HS, Kim WH 2002. Promoter methylation and silencing of PTEN in gastric cacinoma. Lab Invest, 82: 285-291.

Knudsen KA, Frankowski C, Johanson KR, Wheelock MJ 1998. A role of cadherins in cellular signaling and differentiation. $J$ Cell Biochem, Suppl 30-31: 168-176.

Madhavi R, Guntur M, Ghose R and Ghosh PK 1990. Double minute chromosomes in the leukocytes of a young girl with breast carcinoma. Cancer Genet Cytogenet, 44: 203-207.

Malkhosyan SR 1998. Molecular karyotyping of breast cancer by DNA fingerprinting. Cancer Detection and Prevention: 22 supplement.

Matzke MA, Mette MF, Kanno T, Matzke AJ 2003. Does the intrinsic instability of aneuploid genomes have a causal role in cancer? Trends Genet, 19: 253-256.

Mayama T, Fukushige S, Shineha R, Nishihira T, Satomi S, Horii A 2000. Frequent loss of copy number on the long arm of chromosome 21 in human oesophageal squamous cell carcinoma. Int J Oncol, 17: 245-252.

Mitelman Database of Chromosome Aberrations in cancer 2001. http://cgap.nci.nih.gov/chromosomes /Mitelman

Moorhead PS, Nowell PC, Mellman WJ, Battips DM, Hungerford DA 1960. Chromosome preparations of leukocytes cultured from human peripheral blood. Exp Cell Res, 20: 613-616.

Nordenson I, Beckman K, Liden S, Stjernberg N 1984. Chromosomal aberrations and cancer risk. Hum
Hered, 34: 76-81.

Nunez M, de Penchaszaden UB, Pimentel E 1984. Chromosome fragility in patients with sporadic unilateral retinoblastoma. Cancer Genet Cytogenet, 11: $139-141$.

Ochi H, Wananabe S, Furnya TT, Sugane S 1998. Chromosomal fragility of lymphocytes from breast cancer patients in relation to epidemiological data. Jpn J Cancer Res, 79: 1024-1030.

Persons DL, Croughan WS, Borelli KA, Cherian R 1998. Interphase cytogenetics of esophageal adenocarcinoma and precursor lesions. Cancer Genet Cytogenet, 106: 11-17.

Rabinovitch PS, Reid BJ, Haggitt RC, Norwood TH, Rubin CE 1989. Progression to cancer in Barrett's esophagus is associated with genomic instability. Lab Invest, 60:65-71.

Ray GN, Shahid M, Hussain SA, (2001) Status of chromosome breaks and gaps in breast cancer. A follow up study. Cancer Genet Cytogenet, 130:155159

Richard F, Muleris M, Dutrillaux B 1994. Chromosome instability in lymphocytes from patients affected by or genetically predisposed to colorectal cancer. Cancer Genet Cytogenet, 73: 23-32.

Rommel Rodriguez B, Angelo C, Mathes Mashro V, Philbert PMP, Casartelli C 1992. Infiltrating ductal breast carcinoma: cytogenetic analysis. Abst of Third European workshop on cytogenetics and molecular genetics of human solid tumors, Portugal, 159

Rosenblum-Vos LS, Meltzer SJ, Cox JL and Schwartz S 1993. Cytogenetic studies of primary culture of oesophageal squamous cell carcinoma. Cancer Genet Cytogenet, 70: 127-131.

Roy SK, Trivedi AH, Bakshi SR, Patel RK, Shukla PH, Patel SJ, Bhatavdekar JM, Patel DD, Shah PM 2000. Spontaneous chromosomal instability in breast cancer families. Cancer Genet Cytogenet, 118:52-56

Scappaticci S, Maraschio P, del Ciotto N, Fossati GS, Zonta A and Fraccaro M 1991. Chromosomal abnormalities in lymphocytes and fibroblasts of subjects with multiple endocrine neoplasia type I. Cancer Genet Cytogenet, 52:85-92.

Shiraishi K, Okita K, Kusano N, Harada T, Kondoh S, Okita S, Ryozawa R, Noguchi T, Iida Y, Akiyama T, Oga A, Fukumoto Y, Furuya T, Kawauchi S, Sasaki K 2001. A comparison of DNA copy number changes detected by comparative genomic hybridization in malignancies of liver biliary tract and pancreas. Oncology, 60: 151-61.

Takabayashi T, Lin MS, Wilson MG 1983. Sister chromatid exchanges and chromosome aberrations in fibroblasts from patients with retinoblastoma. Hum Genet, 63: 317-319. (c.f.) Barrios L, Caballine MR, Miro R, Fuster C, Guedea F, Subias A, Egozene J 1991. Chromosomal instability in breast cancer patients. Hum Genet, 88: 39-41.

Tang JC, Wan TS, Wong N, Pang E, Lam KY, Law SY. Chow LM, Ma ES, Chan LC, Wang J, Srivastava G 2001. Establishment and characterization of a new xenograft-derived human esophageal squamous cell carcinoma cell line SLMT-1 of Chinese origin. Cancer Genet Cytogenet, 124: 36-41. 
Udayakumar AM and Bhargava MK 1995. Double minutes and premature chromosome condensation in blood lymphocytes of four breast cancer patients. Anti Cancer Res, 15: 1577-1580.

Udayakumar AM, Bhargava MK 1994. Chromosomal aberrations in peripheral blood lymphocytes of breast cancer patients prior to any therapy. Ann Genet, 37:192-195.

Usmani BA 1993. Genomic instability and metastatic progression. Pathobiology, 61: 109-116.

Wang N, Kantor A, Saldat K, Linluist K, Strand R, McLaughlin H, Schuman L 1982. Higher frequency of chromosomal aberrations and polymorphism in patients with renal carcinoma. Am J Hum Genet, 34: $78 \mathrm{~A}$.

Wang X, Xiao F, Wang M 1998. Establishment of two human esophageal carcinoma cell lines and their cytogenetic analysis. Zhonghua Zhong Liu Za Zhi, 20: 5 -8.

Yadav M, Hopwood VL, Multani AS, Mansfield PF, Takahashi Y, Mcintypre BW, Udagawa T, Pathak S 1996. Non-random primary and secondary chromosomal abnormalities in human gastric cancers. Anti Cancer Res, 16: 1787-1795. 